\title{
準備委員会企画シンポジウム 4
}

\section{授業改善 \\ —心理学からの提言}

\section{To Improve the Teaching and Learning in Your Class: From the Viewpoint of Psychology}

\author{
Masaharu Kage, Kiyomi Akita, Mutsumi Imai, Takashi Kusumi, Toshihiko Endo, \\ HiroAKI ISHIgURO, MASAHIRO NASU AND HIROMI KOBAYASHI
}

\begin{tabular}{|c|c|c|c|}
\hline 画·話題提供 & 鹿 毛 & 雅 治 & (慶應 義 塾 大 学) \\
\hline 会 & 秋 田 & 喜代美 & （東 京 \\
\hline 題提供 & 今 井 & むつみ & (慶 應 義 塾 大 学) \\
\hline 題提供 & 楠 見 & 孝 & （京 \\
\hline 提 & 遠 藤 & 利 彦 & （東 \\
\hline 提 & 石 黒 & 広 昭 & （立 \\
\hline & 奈 須 & 正 裕 & 智 大 \\
\hline 定討 & 小 林 & 宏 已 & (早 稲 田 大 \\
\hline
\end{tabular}

\section{企画趣旨}

\section{鹿毛雅治}

よりよい授業を創り出すことは教師にとって永遠の 課題であろう。そもそも「よい授業」とはどのような ものなのか，そして授業をよりよくするとはどのよう な営みなのだろうか。そのような問いにあらためて向 き合い，教師が具体的な実践に活かしていくためのヒ ントを心理学の理論に基づいて提供し，ともに考えを 深めていくことを目的として，本公開シンポジウムを 企画した。

具体的には, 心理学の研究領域として「学習・発達」, 「思考」,「感情」,「動機づけ」,「社会・文化」を取り上 げ，各話題提供者が「よりよい授業を教師が創ってい く上で大切にすべき点」について, 心理学理論に基づ いて整理し，提言した。また，授業研究，授業実践の 観点から指定討論者がコメントし, 登壇者相互で討論 を行った。

\section{話題提供}

\section{発達・学習科学からの提言}

今井むつみ

これからの世の中を生き抜くために大事なのは，論 理的思考能力，あるいは批判的思考力と言われる思考
力であるということを最近いたる所で耳にする。大学 入試もそのような能力を問うことが求められるように 変わる。しかし, 論理的思考力, 批判的思考力という 概念は極めて抽象的で, 行政サイドも教育現場もこれ らのことばを曖昧なまま，様々な解釈を許す形で使っ ている印象がある。これは, 思考力, 判断力を束ねて いる「知識」の意味が，人によってずいぶん違って受 け止められていることが根にあるのだと思う。本発表 では「生きた知識とは何か」という問題を発達・学習 科学の視点から新たに捉えなおし，「生きた知識」をど のように身につけ，より良く学ぶことができるのかを 提案した。

\section{「生きた知識」とはどういう知識か}

これまでの教育観では，知識は客観的な事実として 扱われてきた。知識はきれいに切り取ることができる 断片として存在し，その断片を人から教えてもらう。 母語は, 様々な知識の中でも「使うための知識」,つま り「生きた知識」の代表である。言語を使えるように なるために，子どもは何をどのように学んでいるのだ ろうか。そもそも言語は, 分厚いテキストに書き込ま れた音韻の規則，文法，単語の意味をすべて「暗記」 しても使えるようにはならないのである。

言語はあまたの要素が互いに意味をもって関係づけ られてつくられたシステムである。語彙の学習を例に 挙げれば，単語を覚えるということは，それまでの時 点で作られている語彙にさらに新しい単語をただ単に 加えていくことではない。新しい単語を語彙に入れる ために，子どもはその単語の意味を自分で考える。そ のときには，すでに知っている単語との関係を考え， 語彙のシステムの中での新しい単語の収まる場所を考 える。新しい単語が語彙に入れられたら，その単語と 関係する単語の意味も変わりうるし, 語彙のシステム 自体も変動する。 
これは言語に限らず，どのような分野の知識にも言 えることである。最も役に立つ「生きた知識」とは, 常にダイナミックに変動していくシステムなのである。

\section{「生きた知識」を獲得するには}

では子どもが「生きた知識」を獲得するにはどうし たらよいのだろうか？ 子どもはすでに切り取られた 知識片を「はい」と渡されて, それを暗記しているので はない。分節されていない知識の塊をどのように切り 出していくかを自分で見つけなければならない。言語を 使うために子どもは外にある知識を「教えてもらう」 のではなく「自分で探す」。要素を見つけながら, 要素 どうしを関連づけ, システム自体も発見していく。自 分で見つけるから，すぐに使うことができるのである。

「生きた知識」は目の前の問題を解決するのに使うこ とができるだけではない。新たな知識を創造するため に使うことができる。新たな創造はゼロからは生まれ ない。すでに知っている知識を様々に組み合わせるこ とで生まれる。創造力の源泉は持っている知識を使っ て想像することである。人は,「生きた知識」と想像力 を組み合わせることによって，無限に新しい知識をつ くっていくことができる。それに対して，断片を覚え ただけの知識は，使うことができない。使えないから， 他の知識と組み合わされて新しい知識を生むこともな いのである。

\section{学び方の学びと教師の役割}

では子どもが「生きた知識」を身に着けることがで きる教育とはどのような教育だろうか？ 昨今,「アク ティヴ・ラーニング (主体的な学び)」ということばが教 育界のキーワードになっている。ただし，それをどの ように実現するかという点では一枚岩ではないようだ。 子どもが自分で発見することが大事というと, すべて を子どもに任せて放っておくのがいちばん良い，とい う䛊解をされやすい。しかし, それは違う。例えば, 幼児にブロックや粘土など特定の機能や目的をもたな い玩具をそのまま渡すだけでは，子どもは何をしてよ いのかわからず，興味をもつことができずに放り投げ てしまうだろう。

他方, できるだけ大量の知識を「教えよう」「教わろ う」という教育観, 学習観を教える側, 教わる側の双 方が持っていると，知識の断片をとにかく「覚える」 という従来の教育観, 学習観に必然的に行き着いてし まう。そうならないようにするためには, 学校で何を しなければならないか。まず第一に, 学校は「知識を 覚える場」ではなく, 知識を使う練習をし, 探究をす る場となるべきだ。知識を使う練習とは，持っている
知識を様々な分野でどんどん使い, それによって, 新 しい知識を自分で発見し，得ていくということである。 それこそがアクティヴ・ラーニングの本質である。

もうひとつの学校教育の重要な役割は, 誤ったス キーマの修正である。スキーマと概念の根幹となる知 識である。人はだれでも日常的な経験に基づいて一般 化をし，スキーマをつくる。一般化はいつも正しいと は限らない。例えば初めてイルカを見て，「これはイル カだ」と教えられたとき,「イルカは海に住む大型の生 き物全般」と思い, サメも「イルカ」であると思いこ むというょうに。スキーマが誤っていると, それに関 して何か新しいことを読んだり聞いたりしても，その スキーマに合わせる形で理解してしまう。スキーマに 合わない情報はそもそも取り込まれない。したがって， 誤ったスキーマは学びの障害になるので修正しなけれ ばならない。

しかし,「間違っている」と指摘して正解を教えても, 誤ったスキーマは修正されないことが認知科学の多く の研究で繰り返し報告されている。つまり, 誤った思 い込みを持っているときに教えられた正解は「生きた 知識」にならないのである。では思い込みはどのよう に修正されるのか。学習者が, 自分の思い込み理論と 目の前の現象が合わないことを目の当たりにして, 自 分の理論が間違っているかもしれない, と疑いを持っ たときにのみ思い込みは修正されるのである。

このための教師の役割は非常に重要である。教えな いことはがまんすることである。しかし，放置するの ではない。生徒がどのような䛊認識をもっているのか を分析し, 理解し, さらに, 生徒が自分の誤認識が誤 りであることを自ら発見することができるような状況 をつくらなければならないのである。そのために教師 がしなければならないことは, 自らが「より良い学び」 について探究することであり, 学びの達人になること である。

\section{コンピテンシー育成のための授業改善}

楠見 孝

これまでの授業は, 各教科において知識・スキルを 教えることを重視してきた。今後の授業改善として, コンピテンシー（知識・スキル・態度と価值を統合的に働かせ る能力) 育成（e.g., OECD Education 2030）を重視した 3 つ のことがらを提案したい。

\section{教科および教科横断的な知識の育成}

第 1 は, 教科および教科横断的な知識や関連付ける 思考態度の育成である。そのためには, 各教科そして 
総合的な学習の時間において, 教科横断的知識も教え ることが大切である。さらに, それらの知識が職業や 生活の場，未来の社会で，どのように使われ，役立て ることができるかという転移可能性を, 学習者に考え させる（例：生物や地理で, 森林破壊について取り上げる。数 学において, 混雑緩和のシミュレーションを取り上げる)。そし て, 学習者の関連付け, 類推能力を高め, 知識の転移 可能性を高める。

PISA 2009 の生徒への質問紙における勉強方法の設 問「自分自身の経験と関連付けることによって, 教材 を良く理解するようにしている」について，「ほとんど しない」と回答する比率は，17 カ国の中で日本 $(41 \%)$

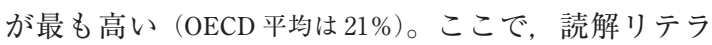
シー得点は,「ほとんどしない」と回答する生徒 (507 点) は「ほんとんどいつもする」と回答する生徒 (557 点)よりも50 点平均点が低い。このように, 自己の 経験との関連付けをする生徒の成績が良い傾向は, 科 学的リテラシー, 数学的リテラシーにおいても, そ して他の国においてもみられていた。また，「新しい 情報をほかの教科で得た知識と関連付けようとする」 に対しては，「ほとんどしない」と回答する比率は日 本 $(29.9 \%)$ が最も高い $(\mathrm{OECD}$ 平均は $13.5 \%)$ 。ここでも， 教科を越えた関連付けをする生徒の成績が良い傾向が みられていた（国立教育政策研究所, 2010）。

さらに, 探究的学習に重点をおいたスーパーグロー バルハイスクールにおいて, 関連付けの思考態度の向 上をみるために, 高校 3 年間の追跡調査を行ったとこ ろ，「授業で学んだことを，ふだんの生活や社会の出来 事に当てはめて考えてみる」、「授業で新しく学んだこ とを, 他の教科で得た知識と関連付ける」への肯定回 答率は, 高校 1 年（文理共修コース） 7 月では $61 \%$ と $71 \%$ であったものが, 高校 3 年 1 月には $81 \%$ と $83 \%$ に 上昇していた。また，交差遅れモデルによる分析の結 果, こうした関連付けの態度は, 次時点での批判的思 考態度や探究スキルの獲得を促進する効果があった（楠 見, 2017 には, 2 年目までのデー夕を掲載)。

これらの結果は, 教科横断的知識および関連付けの 態度の重要性を示している。

\section{認知的・メタ認知的スキルを育成}

第 2 は，第 1 の知識を生かすために, 認知的・メ夕 認知的スキルを育成することである。各教科の授業に おいて, 教科固有の考元方 (例: 科学的思考法, 歴史的思考 法), 認知的・メ夕認知的スキル (批判的思考法や探究の手 法, 学習方略など) を教えて, 学習者に意識させ, 習得・ 活用できるようにする。さらに，探究的課題などの中
で活用，応用できるようにする。

こうした探究的学習に関わる認知的・メ夕認知的ス キルが，どのように育成されるかを，先に挙げたスー パーグルーバルハイスクールにおける特色ある授業科 目を例にみてみる。1 年次の「ロジカルサイエンス」 では批判的思考スキル，「グローバルインタラクショ ン」では課題設定・解決のスキルを学び, 2 年次の 「アカデミックラボ」では, グループに分かれて探究学 習を進め, ポスター発表等の実践を通してスキルを学 ぶ。 3 年次の「課題錬成」では，それを英語で発表す ることで英語コミュニケーション能力も育成している。 生徒達への継続調査の結果, 探究的学習の各スキル（探 究, 読解, 表現) を身に付けた程度の自己評定值に向上 がみられた。また, 探究活動において，(a) 探究した 「問い」，(b) 印象に残ったこと，(c) さらなる「問い」 について自由記述を求めた，その結果，いずれの問いに おいても記述の量的・質的向上がみられた（楠見, 2017）。

また, 別のスーパーサイエンスハイスクールの特色 ある授業科目をみてみると, 1 年次「自然探究の方法」 では探究スキルを身に付け，2 年次「自然科学探究」 では環境調査などの探究を進めている。1, 2 年次の追 跡調査を行った結果, 探究スキルを身に付けた程度が 翌年の探究スキルだけでなく教科学力にも正の影響を 与えていた（楠見, 2018）。

\section{態度と価値の育成}

第 3 は，態度と価值の育成である。そのためには, 授業において答えが 1 つでない論争的なテーマ（例：移 民，エネルギー）を取りあげて，討論することを通して， 他者の多様な価值観を知り, 相手の価值観や信念を尊 重し, 合意形成する経験を通して学ぶことが大切であ る。そのほかにも, 授業において, 背景の異なるゲス 卜を招いたり, 教室の外に出て, 多様な他者と出会い, 課題解決の困難を知り, 協働する経験を重ねることが 考えられる。

滋賀大学教育学部附属中学校の「科学技術科」の実 践では，理科と技術科そして社会科の教員が，チーム ティーチングによって, エネルギー環境問題を, 対立 する立場に基づいて説明したうえで, 生徒自身が $1 つ$ の答えのない問題の解決に取り組んでいる。具体的な 目標としては,（1）現状を正しく認識させ, 様々な視 点から考察を加えようとする態度, (2) 生徒自身が判 断，（3）結論に満足させない,（4）答えがいくつも存 在することを理解することをあげている。生徒たちは この授業を通して, 思考態度やスキルを獲得し, 社会 における問題解決に応用できるようになることを目指 
している（河野・澤田・太田・七里, 2012）。

\section{授業改善一「排情主義」から「活情主義」へ}

\section{遠藤利彦}

心理学は長く, 理性 (reason) と熱情 (passion) の対立 的構図を前提視するソクラテス (Socrates) およびプラ トン (Plato) 以来の西欧思潮の系譜の中で, 他種とヒト を分かつ顕著な特質たる理性あるいは言語, 思考, 記 憶といった人の心の認知的機能により強い関心を向け, 熱情あるいは人の心の感情的側面については，その学 知的追究を相対的に意ってきたと言えるかも知れない。 しかし，近年，こうした状況は大きく変わりつつある。 感情に潜在する生物学的および社会的な機能性や合理 性に光が当たるようになり，感情は理性あるいは認知 と対立するどころか, むしろ, それらと協調的に結び つき，人の種々の適応性を高度に支えるものと考えら れるようになってきている。今や, 心理学は確実に, “mind”（知性的な心）と“heart”（感性的な心）との調和 的融合に関心を移行させてきているのである。

もっとも, こうした心理学における方向性の転換は, 未だ教育の現場にはあまり波及していないのかも知れ ない。子どもが徐々に, 感情中心の生活世界から離脱 し，理性中心の生活世界へと参入することがあるべき 発達であり，それを促し可能ならしめるのがあるべき 教育であるという暗黙の見方が，今なお少なからず教 育現場で一つの通奏低音をなしているように思われる。 感情は，少なくとも授業という場において，相対的に 好ましからざるもの，制御されるべきもの，場合に よっては時に積極的に排除されるべきものとして見な されているところがあるのではないだろうか（「排情主 義」)。より具体的に言えば, 感情は, 多くの場合, 特 定の学習目標の達成を妨げるものとされ, むしろ, そ れを徹底管理し得ること，すなわち感情抑制の重要性 ばかりが㓌に陽に児童・生徒に対して説かれるような ことも少なくはないのだろう。

無論, 教育の実践あるいはそのための研究において, 感情がきわめて扱いづらい厄介なものであることはい かなる意味でも否みがたいことである。そもそも，感 情は, いつ生起し消失するかが読めない, 謂わば神出 鬼没のものであり, とりわけ教室のような集団状況に なると，その力動的変化は予測することがきわめて困 難である。また，例えば教師が览童・生徒の感情表出 を抑止することはある程度可能でも，意罒的にある特 定種の感情を生起させたり，またその強度を適度に調 整したりすることは容易ではない。遠く古に, アリス
トテレス (Aristotle) はソクラテスやプラントとは違い, 正負あらゆる感情において，その程度が中庸である限 りにおいて機能性が適切に発揮されると主張した訳で あるが，そのほどよさを具現することは相対的に難し いものと言える。さらに, 感情は顕在的であっても一 過性で移ろいやすいものであるため, 殊にリアルタイ ムでの測定や評価が困難であり, その分だけ, 感情の 授業等に対する影響や効果を検証しづらいことも確か である。

しかしながら, いかに感情にかくなる原理的困難性 が伴うにせよ，学校や教室が本源的に，実に多様な感 情が色濃くまた力動的に交錯する場である限りにおい て，どのような形であれ教育的営為に携わる者は，本 来, この感情に対する刮目を怠ってはならないはずで ある。特に, 感情研究の現況として, 感情に絡む様々 な心理学的要因が, 児童・生徒の心理社会的適応性に 深く絡み得ることが実証されてきていることからして， 授業現場においても，専ら制御されるべきもの（regulatee）としてばかりではなく，むしろ授業を適切に制 御・調整するもの (regulator) としての感情およびそれ が現にもたらし得る教育的効果がもっと真摰に問われ て然るべきではないだろうか。半ば当然のことながら， 感情は, 特定教科の教材の理解や学習等に直接的に寄 与するというよりも, 多くは, 児童・生徒の動機づけ への影響を介して, 何らかの教育効果をもたらし得る ものと言える。

そして，そうした動機づけへの影響を想定した場合 に,まず注視されるべきものに, 児童・生徒と教師と の信頼関係が挙げられよう。これまでの心理学におい て, 子どもと大人との信頼関係の構築・維持に対して, 最も多く研究されてきているものにアタッチメントが ある。アタッチメントとは, 個人がある危機的状況に 接したり，それが予期されたりする際に生じる恐れや 不安等のネガティヴな感情を特定他者への近接を通し て制御・調整し, 安心感の確保と自発的な探索を可能 ならしめる心理行動的および神経生理的システムと定 義されるものであるが, 従来, その研究の主たる対象 は，乳幼児期の子どもと養育者等との関係性であった。 しかし, 近年, 主に欧米圈において, 児童期以降の子 どもをターゲットとする研究が飛躍的に進展し, 殊に 学校や教室の中での, アタッチメント対象としての教 師の役割の大きさが深く認識されるに至っている。教 師が, 児童・生徒がネガテイヴな感情に陥った場合の 安全な避難所 (safe haven) として, また新たに探索活動 を起こす際の安心の基地（secure base）として機能して 
いる場合に，児童・生徒の自尊感情や学習面でのパ フォーマンスも含め, 種々の適応性が総じてすぐれる 傾向が見出されているのである。

またこうした個々の児童・生徒と教師との関係性 は, 児童・生徒一人ひとりの感情の経験や表出の特質 および児童・生徒同士の関係性等と合わさり，それぞ れの学級に特異な感情風土（emotional climate）を構成す るに至るものと考えられる。そして，それは，個々の 授業においても，例えば発言のしやすさ，過ちをした 場合の許容性, グループ単位での共同学習への取り組 み等に影響を及ぼし, 児童・生徒の授業全般への動機 づけやエンゲージメント等を左右するものと言い得る。 無論, こうした感情風土は, 学級の構成員の組み合わ せといった偶発的要因に左右されるところも大きい訳 であるが, 教師の個々の児童・生徒の顕在・潜在シグ ナルに対する敏感性および児童・生徒同士の関係性や 集団力動といった集団全体に対する敏感性, さらには 教師自身のメンタルヘルスやモラール（志気）等によっ て規定される部分も多分にあることが明らかになってお り, その意味で, 授業改善の素地をなすものとして, そ こに介入を試みることには大きな意義があると言えよう。

さらに, これは狭く授業改善のみに留まるものでは なく，もっと包括的な見方ということになるが，長期 目線で, 児童・生徒の感情面の賢さをじっくりと涵養 していくことが, 個々人の社会情緒面の適応性はもと より, 結果的に, 認知能力や学力の向上にも好影響を もたらす確率が高いということに，私たちはもっと着 目して然るべきであろう。この感情面の賢さとは, 近 年の心理学の術語で言えば感情知性 (emotional intelligence）ということになろうし，また教育経済学の術語 で言えば非認知スキル (non-cognitive skills) ということ になろうが，それらに関わる最近の実証研究は，これ らの力が, 将来的に, 人の知情意全般に亘る適応性や 高パフォーマンス，そしてまた well-being を可能なら しめる最も重要な鍵の一つであることを見出しつつあ る。これらの力は, 広く自己と社会性に関わる心理学 的コンピテンス，換言するならば，自己を尊重しさら にその可能性を切り拓く力, および集団の中に溶け込 み他者との関係性を形成・維持する力, 加えてその両 側面を支えるものとしての感情を適切に制御・活用す る力と言い得るものであり, 勿論, 学力スコアのよう に容易に可視化できるものではないが，そこに焦点化 した創意工夫ある教育が豊かに展開されることが，こ れから未来の人間社会における一つの大きな課題にな るのだろう。
授業改善に向けて私たちが志向すべきは，今や，「排 情」ではなく「活情」なのである。

\section{学習者の視座から環境をデザインする一動機づけ研究 の立場から}

鹿毛雅治

学習者の動機づけは一般に「学習意欲」と呼ばれ, 授業を実践する上で最も重視されるポイントの一つと して長らく位置づけられてきた。そもそも動機づけと は「行動の生起, 維持, 方向づけプロセス」を指し, 意欲とは意志（やり遂げようとする心理）と欲求（〜したい と感じる心理）の複合語であると解されることから，学 習意欲とは「学びたい」と感じ，その学習を「やり遂 げよう」とする心理を意味する（鹿毛, 2013)。この学習 動機づけに関してその量的な側面（学習活動時間など）が 着目されがちであるが, これまでの膨大な研究を通じ て，むしろその「質」に着目すべきことが明らかに なっており, その多様な質について検討が行われ，あ わせて理論化が進められてきた。

これまでの学校教育では, 主に知識や技能の習得に 重点が置かれる傾向があったため, 教師には「教える」, 学習者には「答える」という役割が求められてきた。 また, 教師と学習者の関係は「学ばせる一学ばせられ る」という関係になりがちで, そこでの動機づけは 「〜させる」という「使役の原理」に支配され，テスト や点数, 成績などが「賞罰」として機能するような外 発的動機づけに基づく学習が促されるという実態が遍 在していた。このような外発的動機づけについては, その継続性や学習成果の質といった観点から効果の限 界や弊害が明らかにされてきた。

それに対して，興味や自発性を特質とする内発的動 機づけは，かねてから教育的に望ましいとされてきた。 また，近年の達成目標に関する研究の進展，とりわけ 熟達を目的とするマスタリー目標が学習成果に及ぼす ポジティブな影響に関する頑健な知見を鑑みるなら， 学習者自身の思考や表現, 主体的な態度を重視して認 識の深まりを目指す今日の学校教育においては, 内発 的動機づけを基軸とした「主体性の原理」に基づいた 教育実践を展開することが一層求められているといえ よう。そこでの教師と学習者の関係は, 学習者が自分 自身の「問い」を持って自発的に学んでいくプロセス を教師が促したり，支えたりするという「自ら学ぶー促 す, 支える」という関係となり，教師は「直接，教え る」というよりも, 教育環境をデザインし, 柔軟に学 習の場を調整するといった間接的な教育の役割を担う 
ことになる。すなわち，「使役の原理」から「主体性の 原理」へと動機づけの発想を転換する場合, 学習者を 学ぶ「主語」として積極的に位置づける必要が生じ, 教師には「他者である学習者」の学習体験を常に想像 するような態度を基盤として, 授業を具体的な学習環 境として創造することが求められることになる。

学習者を「主語」とした場合, 一体, 彼らは授業を どのように体験しているのだろうか。動機づけ研究の 観点からは，このように「学習者に体験される授業」 という観点から授業改善について検討することが有益 である。その「体験」を探るための出発点として, 現 在進行形の一瞬一瞬において学習者が課題に向き合っ ている様子, とりわけ「今, ここ」で動機づけられて いる学習者の姿が手掛かりになるだろう。そこには学 びの「真顔」や「笑顔」があり，それらは「集中」, 「熱中」,「夢中」といった学習動機づけを支える要素の 身体表現として理解することができる。このような知 情意が一体化した没頭状態は「エンゲージメント」と 呼ばれ，パフォーマンスの向上プロセスを支える心理 状態として近年の動機づけ心理学で着目されている。 すなわち, エンゲージメントとは, 課題に正対して取 り組んでいる心理状態を指し, 専念する, 持続する, 試行するといった行動的側面, 興味を持つ, 楽しむと いった感情的側面, 注意を向ける, 方略を吟味すると いった認知的側面の三側面を併せ持った心理状態を指 す。このような学習活動に扔ける「今，ここ」(here and now）における学習者の姿に着目することが授業改善に 向けた有益な情報源となる。

上述した学習意欲の概念規定に基づくなら, エン ゲージメント状態とは,「学びたい」といった課題に没 頭する心理状態 (欲求) と, 「学び遂げる」といった目 標を達成しょうとする心理状態を（意志）併せ持った姿 だと理解することができる。動機づけ研究では, この ようなエンゲージメント状態の規定因について価值要 因と期待要因の二つに大別できることを明らかにして きた。価值要因とは「なぜ私は学ぶのか」「(学習が $)$ 私 にとって価值あるものだろうか」という問いに関わる 学習動機づけの規定因であり, 当人にとっての学習の 理由を意味する。具体的には, 点数や成績のためと いった「賞罰系」, 自尊心の維持や高揚が理由となる 「自尊・承認系」, 知りたい, 上達したいという「興 味・関心系」, 大切だから，意味があるからといった 「意義・コミット系」に区別できるが，より自律的な 「興味・関心系」や「意義・コミット系」の学習意欲が 持続性やパフォーマンスの質という観点から望ましい
と考えられている(鹿毛, 2013)。一方, 期待要因とは 「(学習活動や学習目標の達成が) 私にはできるだろうか」と いう学習者自身の問いに関わる動機づけの規定因であ り, 失敗の予測が課題従事前のあきらめや無関心, 課 題従事中の不安, 困惑, 不注意につながるのに対し, 成功の予測は課題従事前の興奮や幸福感, 課題従事中 におけるスキルや理解の向上に基づく満足感や誇らし さに結びつくとされている。以上のことから, 学習者 の興味や関心を喚起し, 意義が感じられるような課題 に対して，まずは活動に従事することが可能であり， しかもその活動を通して学習目標に達成できるという 見通しを学習者が持てるような現在進行形の状況を夕゙ イナミックに展開することが教師の課題であることが 示唆される。

「主体性の原理」に基づく授業改善は極めてチャレン ジングな仕事である。まずは, 学習者一人ひとりの体 験という視座に立脚し, 学習者の学習プロセスの個人 差を丁寧に理解しようとするという態度が求められる に違いない。一方で, 学習者の学習意欲を促すような 課題という観点から教材研究を行い, 魅力的な単元開 発をすることが求められよう。その上で学習環境を構 想し, それを具体化するとともに, 学習環境をダイナ ミックな現在進行形の場ととらえて柔軟に展開するこ とが教師に求められているのである。

\section{子どもたちは授業で何を学んでいるのか一「アーティス ト」としての学習者}

石黒広昭

家庭で，道端で，あらゆる場所で学習が起きている。 その学習は意識化されることもあるだろうが, 通常は 学んでいるという自覚がなく, いつの間にか身につけ てしまう。伝統的な社会では, 身につけた技能は「誰 に教わったものではない」というそうだ（原, 1989)。そ れに対して, 学校で学ぶ知識はVygotskii (1934 柴田訳 2001）が「科学的概念」と呼んだように, 学ぶ内容を自 覚的に習得する。学習は知識や技能の変化として経験 されるが，それらが相互に影響し合うことで，人格の 変容 (transformation) が生じ,「発達」をもたらす。実践 は常に他者に開かれているという意味で社会的であり， 豊かなものとなる。ただし, 発達は社会的に望ましい とされる方向に常に進むわけではない。

授業は子どもたちが日々学習する場であり, 実践の 一つである。授業という場において子どもたちは何を 学んでいるのであろうか。そこで, 子どもたちはどの ように発達しているのであろうか。残念ながら, さま 
ざまな調査に現れる日本の子どもたちの学習内容に対 する興味・関心や自尊感情の低さは,「学ばされ上手」 ではあっても「自ら学ばない」子どもたちの存在を示 唆している。学びを楽しめない子どもたちの指摘は何 も今に始まったことではないし，学校や授業だけがそ の責を負うべきものでもない。しかし，授業を通して 子どもたちが学びを楽しみ, 未知の世界に向かうなら どんなにかよいだろう。学びを希求する子どもたちは どのように生まれるのか。今回の報告では, 学習と発 達の社会性, 歴史性を重視する社会文化歴史的アプ ローチの立場から学校的学習, そして学習者にとって の学習実践を検討する。

最初に典型的な授業の特徵を確認しよう。大学での 留学生に対する授業場面（石黒, 2014) である。「薬を飲 む（）元気になります。」の文が提示され，そこに 「なら，と，たら(だら)」のどれを入れたら適格文にな るのかを問う状況である。最初に学生 Aが「薬をのむ ならすぐ元気になります」と答える。それに対して指 導者は「どうですか?」と学生らに確認を求める。す ると学生 Bが「飲んだら 飲むと」といい，それを指 導者が教室全体に戻す。その後, 学生らは「と」と 「なら」で適格文ができることを確認し, 最後に皆で再 び「飲んだら」の正誤を確認するという流れだ。この 時, 学生も指導者も笑っており,「だら」が誤答である ことは皆にとって自明であった。ここで授業らしさを 構成しているのは 2 点ある。一つは正解をすぐに確認 せず，学習者が自ら気づくのを待った点，もう一つは 正誤が言語知識によってではなく, 授業内のやりとり から察せられたという点である。これは擬似理解とい われる現象である。言語で言語を教える外国語の授業 ではよくあることだ。

では, 授業は学習にとって役立たないと言い切って よいのだろうか。別の留学生は「日本語を覚えたのは, 学校の授業よりテレビだな。家で暇なときにドラマを 見ていて，わからないことがあったら，すぐにメモを しておいて, 次の日学校の先生に聞いた。教科書は授 業のときは開いているけど，家に帰ったら全然開かない。 それより,テレビを一生けんめい見て日本語を覚えた」 （江崎・森口, 1988, p. 121）と述べている。これは学校の授 業は役立たないといっているようだ。だが，この学習 者は自分でまず学び，問いを持って授業に臨んでいた。 授業は重要な学習資源であった。二つの例からわかる ことは, 授業や教科書が教授者の教授資源として有効 性を発揮することと，学習者にとってそうであること とは違うということだ。理念型として二つの学習者の
タイプ（石黒, 2014）を考えてみたい。一人は教室で指導 者が意図的教授を行う上で必要とする「学習者 I」で ある。もう一人は文字通りの意味で何かを学ぼうとす る「学習者 II」である。人は本来世界を探索する, 知 的好奇心に溢れる存在である (Rinaldi, 2004)。しかし， 教室では「教えられたことを学ぶ存在」として位置づ けられてはいないだろうか。指導者は「教えられるこ とがうまい学習者」を「主体的に学ぶ学習者」と言い 換えていないだろうか。

社会文化歴史的アプローチでは, 既に 30 年ほど前に 学校で行われる学習をそれ以外の学習と比較し, その 特質を議論している。日常認知研究 (e.g., Rogoff \& Lave, 1984）と総称される研究群である。学校での学習は将来 のための準備であり, 時に準備のための準備となる。 その知識や技能は何かのための知識ではなく, それ自 体に価值があるとされる。習得過程では失敗も許され る。しかし，ブラジルの路上でココナツを売る子の計 算技能（Carraher, Carraher, \& Schliemann, 1985）は生きるた めのものであり，計算間違いは生活を脅かす。波多 野・高橋（1997）は学校と学校外の学習を比較して, 学 校でしかできない学びは保持し, 学校外の学びの良い 点は学校教育に取り入れるべきだとした。確かにそう した改善は「学校を改革する」だろう。しかし, 学校 が学習者 I を求める限り, 演劇などのアートが学校に 取り入れられたり，職場学習が取り入れられたりした としても学習者の学習過程は変わらないのではないか。 実際，そうした試みは多いが，学校での学習は変わっ たのだろうか。

なぜ学習者 I が学校で生まれやすいのか。学校では 自分の学習を自分で管理することが許されない。学習 の対象, 手法, 目標の三つにおいて, 教師や学校に自 由度が与えられるのは学習手法だけであり，「すぐれた 授業」をするためには, 定められた目標にそって学習 対象を最も効果的, 効率的に教授することが求められ る。そこで「すぐれた学習者」となるのは, その枠組 の中で自らの問いをあまり展開せずに，「うまく教えら れる学習者」, すなわち学習者 Iである。では, どうし たらよいのだろうか。発想を変える必要がある。一つ は学校の位置づけの変更だ。教授の中心は学校だが, 学習は学習者が組織する (石黒, 2016)。学習が日常生活 のあらゆる場所で起こるのであれば, 社会全体で学習 を支援する環境を作るべき（Illichi, 1971 小澤・東訳 1977) であり，学校はその一部を担うにすぎないことを自覚 することだ。もう一つは, 学校で学習者をどのように 学ばせるのかではなく, 学習者が学校で学べなくなる 
ことをどのように防ぐのかといった問いの変更である。 人が本来自ら学んでしまう, あるいは, 学びたくてし かたがない存在だとすれば，なぜ人は学習者 II で居つ づけることができないのか。実は学習者 II は教室では 面倒な存在である。先生がそろそろ終わりたいと思っ ても質問するかもしれない。授業の予定調和を許さな い。知的好奇心に溢れ，自らの疑問にこだわる。プラ イドが高く，十分納得ができなければ指示に従わない。 こうした学習者が作る教室は個性的な人の集まりとな り, 当然多様性が高まる。これは知を探求する研究者 コミュニティに近い。そしてまた, 強い知的好奇心を 持って動き回る乳幼児の姿にも似ている。

では，どのようにすれば学習者II であることを妨げ ないのだろうか。それには, 学習者の学ぶ力を信じ, その声を「聴きとる」(Rinaldi, 2004) 力をつけることが 必要である。学習者が自ら知を探究する権利を保障す る必要がある。学びは学習者のものである。子どもの 声を聴かず，学ぶべきことを予準備した先回りした 教授は，子どもを「教えられ手」にすることはできて も「学習者」であることを許さない。発達する人を 「アーティスト」メタファーで捉えることを提案したい。 絵描きや音楽家などの芸術家という意味でアーティス トといっているのではない。他者にどのような評価を 受けようが，自らの好奇心によって知的探究をせずに は生きていけない人を「アーティスト」と呼ぶ。人は 誰でもその人固有の価值観に基づいて生きて抢り，そ れを肯定的に捉えられる時, 自尊感情が高まるのでは ないか。学習者が集う小社会である学校は, 相互にそ のアーティスト性を「承認する」(Tyler, 1994) ことが必 要である。このことは教師もまた学び手として尊重さ れなければならないことを意味する。世代の違う学び の仲間と共に知の探究ができる環境が保証されるべき だ。誰もが「アーティスト」であり続けるために, 教 育心理学には何ができるのだろうか。

\section{指定討論}

\section{改善を待つ授業はどこにあるのか}

\section{奈須正裕}

よりよい授業づくりを目指す教師への貢献において 他の教育諸学と比べても, 教育心理学は多くのアドバ ンテージを持つ。それは, 教育心理学が「事実学」を 基盤としつつも, さらに「技術学」にまで発展し得る 射程の長さと正確さを有するからであり, 発達, 学習, 思考, 感情, 動機づけ, 社会, 人格, 測定・評価など, 圧倒的なまでの領域の幅広さと，すべてに共通する確
かな方法論を兼坟備えているからに違いない。

しかしながら，すべての子どもは有能な学び手であ る，ご言美と称賛は内発的な意欲と学びの質を低下さ せる, 学習は状沉に埋め込まれている, 要素的な暗記 的知識は問題解決には使われない, 非認知的能力は十 分に教育可能である, といった心理学者にとっての常 識が，未だ多くの教師にとっては非常識であり, 授業 づくりに十分活かされていないのはなぜか。「提言」と いうのは中空に向かって放たれるものではなく，ある 種のコミュニケーションであるから，「授業改善」に向 けての「心理学からの提言」についても, どこで改善 を待つ, どんな教師のどんな授業を想定しているかが, さらに問われる必要がある。

まず，ネズミの学習心理学を教わった世代の授業に 対しては, その後の心理学の成果を丁寧に伝え,「なる ほど，だから子どもたちはうまく学べなかったのか」 「じゃあ, これからはそうしてみよう」と思っていただ くことが可能であり，必要であると思われる。

また，教育実習生や新任の教師の授業に対しては, 大学で教わって知ってはいるが実践にはうまく活かせ ていない,つまり「死んだ知識」の状態にあるわけで, 何とか工夫して「生きた知識」にして差し上げたい。 それ以前に, 二度手間になら始う，そもそもの大学 の「授業」を心理学の知見に基づいて抜本的に「改善」 する必要があろう。

さらには, 心理学などほとんど知らないけれど，こ ちらが「提言」したいことなどおよそ先刻承知で，す でに質の高い学びを実現している教師の授業に対し， 心理学者は何ができるのか。そこで為すべきは「提言」 ではなく, さらなる「授業改善」を目指しての「共闘」 なのだろうが, すると期待されているのは, 心理学的 な知見そのものではない。挑戦的な学校や教師と共闘 し, さらなる「授業改善」を目指した探究に, 心理学 も使いながら, 結果的に心理学的な探究もしながら果 敢に挑む「心理学者」の存在と実践は, 過去において も，そしてこれからも，十分に歓迎され，大いに期待 されてもいると思うのである。

\section{授業力の高度化にどう応じるか}

小林宏己

OECD 日本の教育政策に関する報告書発表会見 (2018 年 7 月 27 日，日本記者クラブ）に扔いてアンドレアス・ シュライヒャー (Andreas Schleicher; OECD 教育・スキル局 長) は, 日本の教育制度の高い効果や公平性を評価し たが，一方で新学習指導要領の内容を実現するための 
環境整備，教員の負担を減らす学校運営についてその 必要性に言及した。

新教育課程における中心課題の一つである「主体 的・対話的で深い学び」は,「主体的」「対話的」そし て「深い学び」の三位一体として提起された授業改善 の視点である。このような授業の実現を図るためには， 相当高度な授業力が要求される。それはかつて「カリ キュラム開発に関する国際セミナー」(1974 年) におい てアトキン (J. M. Atkin) が指摘した「工学的アプロー チ」と「羅生門的アプローチ」の対比を想起させる。 特に「羅生門的アプローチ」の特徵とされた「創造的 教授・学習活動」「目標にとらわれない評価（goal-free evaluation)」「教授学習過程の中で教材の価值を発見せ よ」「(教授学習過程) 即興を重視する」などの実現を図 るために,「教員養成」が強調点にあげられていた（文 部省（1975）『カリキュラム開発の研究』)。アトキンの指摘か ら半世紀近くが経つ現在, 新旧の教員構成が大きな交 代期を迎え, 若手教師の比重が増す各学校において, はたして「主体的・対話的で深い学び」はどこまで可 能なのか。

学校現場の授業の多くは未だ定型化された指導から 十分に脱却できているとは言えない。「深い学び」に向 けた授業改善を図るためには，単元べースで次の視点 から指導の改善を図りたい。(1)目標・評価観の変革 (到 達・達成的な目標よりも自己実現的な目標を柔軟に扱う）(2)学 習活動研究の充実（経験が教科等の本質にどう繫がるかを見 通す）(3)単元・本時を構想する原則（子どもの思考のすじ 道（論理）を視野に入れる）(4)教材観の転換（矛盾・暮藤を内 在化させた子どもの思考・表現物を構築教材として活用する) (5)どもの見とりを活かしたカリキュラム・マネジメ ント (実践過程で指導計画案の修正を図る)

「学び続ける教師」であることを具現化するためには， 校内授業研究等の改善を重ね, 教師の省察と自己更新 の機会が保障されなければならない。そのために, 次 の諸点を重視した校内授業研究改革の促進が望まれる。 (a) 授業を核としたクラス・学年・学校づくりを（学 級，専科壁の撤廃，年間全員授業の公開，参観者授業記録の精緻 化)，（b）研究協議会の語りを豊かに深く(児童・生徒の 学びの事実に基づく考察と自らの実践経験を開陳した省察，授業 者への代案性のある批評と相互支援，改善策と全校的課題の発見 と焦点化), (c) 単元構想・教材開発を視野に（単元ベー スで資質・能力の育成を，切実な課題，自己の生き方に関わる探 究を）こうした改革を通じて, 教師文化, 学校システム の革新こそが必要とされている。

\section{引用文献}

Carraher, T. N., Carraher, D. W., \& Schliemann, A. D. (1985). Mathematics in the streets and in schools. Developmental Psychology, 3(1), 21-29. doi:10.1111/ j.2044-835X.1985.tb00951.x

江崎泰子 - 森口秀志 (1988). 「在日」外国人一35 力国 100 人が語る「日本と私」晶文社

原 ひろこ (1989). 極北のインディアン 中央公論社 波多野誼余夫 - 高橋恵子 (2004). 文化心理学入門 岩 波書店

Illich, I. (1971). Deschooling society. London, UK: Marion Boyars Publishers Ltd（イリッチ, I. 小澤周 三・東 洋（訳）（1977）. 脱学校の社会 東京創元 社)

石黒広昭 (2014). 教室における「第二言語教育」の課 題と挑戦一国際移動する子どもたち発達支援にむけ て 立教大学教育学科年報, $57,49-71$.

石黒広昭（2016). 子どもたちは教室で何を学ぶのか 東京大学出版会

鹿毛雅治 (2013). 学習意欲の理論一動機づけの教育心 理学 金子書房

国立教育政策研究所 (2010). PISA 2009 年調查一国際 結果の分析 - 資料集 国立教育政策研究所 Retrieved from http://www.nier.go.jp/kokusai/pisa/ (2018 年 10 月 29 日）

河野卓也 - 澤田一彦 - 太田 聡 - 七里広志 (2012). 科 学技術科の創設によるエネルギー環境教育の実践— 科学的な知識をもとに自ら判断し実践しようとする 態度と能力の育成のために 滋賀大学教育学部附属 中学校研究紀要, 54, 145-150.

楠見 孝 (2017). 高校生の探究的学習スキルと批判的 思考態度の育成（2）一スーパーグローバルハイス クールにおける生徒の 2 年間の成長 日本教育心理 学会第 59 回総会発表論文集, 127

楠見 孝 (2018). 高校生の探究的学習スキルが教科学 力に及ぼす影響—スーパーサイエンスハイスクール における検討 日本教育心理学会第 60 回総会発表論 文集, 503.

Rinaldi, C. (2004). The relationship between documentation and assessment. Innovations in early education: The international reggio exchange. MerrillPalmer Skillman Institute, Wayne State University, 11(1), 1-4.

Rogoff, B., \& Lave, J. (Eds.) (1984). Everyday 
cognition. Cambridge, MA: Harvard University Press.

Taylor, C. (1994). The politics of recognition. In A. Gutmann (Ed.), Multiculturalism: Examining the politics of recognition. Princeton: Princeton University Press. (テイラー, C. (1996). 承認をめぐる政治
A. ガットマン（編） 佐々木 毅・过 康夫 ·向山恭 一（訳）マルチカルチュラリズム（pp. 37-110） 岩波書店)

Vygotskii, L. S. (1934). Мышление и речь; Myshlenie i rech.（ヴィゴツキー, L. S. 柴田義松（訳）（2001）. 思考と言語 新読書社) 